\title{
Comparative Analysis of the Physico-chemical and Antioxidant Properties of Honey Available in Tangail, Bangladesh
}

\author{
MR Linkon ${ }^{1}$, Utpal Kumar Prodhan ${ }^{1}$, Toufiq Elahi ${ }^{2}$, Jalal Talukdar $^{1}$, Md. Abdul Alim ${ }^{1, *}$ \\ ${ }^{1}$ Department of Food Technology and Nutritional Science, Faculty of Life science, Mawlana Bhashani Science and Technology University \\ (MBSTU), Bangladesh \\ ${ }^{2}$ Department of Applied Nutrition and Food Technology, Faculty of Applied Science and Technology, Islamic University, Bangladesh
}

Copyright (C) 2015 Horizon Research Publishing All rights reserved.

\begin{abstract}
The aim of the current study was the comparative analysis of the physical, biochemical and antioxidant properties of Mustard, Litchi, and Nigella honey. The physical parameters include the mean moisture content of Mustard, Litchi and Nigella honey were found $14.32 \%$, $15.27 \%$, and $14.12 \%$ respectively; $\mathrm{P}^{\mathrm{H}}$ content were $6.97,5.8$, 4.78 ; the TSS content were $71 \%, 70 \%$, and $73 \%$ respectively. The biochemical parameters including protein content were $1.103 \%, 0.57 \%$ and $0.985 \%$; mean ash content were $0.2 \%$, $0.19 \%$, and $0.188 \%$, total carbohydrate content were $84.377 \%, 83.97 \%$ and $84.496 \%$ and the minerals contents $\mathrm{Na}$ were $539.238 \mathrm{ppm}, 424.3565 \mathrm{ppm}$ and $588 \mathrm{ppm}$; $\mathrm{K}$ were $239.216 \mathrm{ppm}, 219.017 \mathrm{ppm}$ and1063.774 ppm; Ca were $1710.499 \mathrm{ppm}, 611.4852 \mathrm{ppm}$ and $75.4 \mathrm{ppm}$ for the Mustard, Litchi and Nigella honey respectively. The Antioxidant properties such as polyphenol content were found $42.572 \pm$ $0.00529 \mathrm{mg}$ gallic acid $/ 50 \mathrm{ml}, 30.625 \pm 0.00529 \mathrm{mg}$ gallic acid $/ 50$ $\mathrm{ml}$ and $95.5 \pm 0.00529 \mathrm{mg}$ gallic acid $/ 50 \mathrm{ml}$; flavonoid content were found $1.052 \pm 0.000577 \mathrm{mg}$ catechin $/ 50 \mathrm{ml}, 0.6 \pm$ $0.000577 \mathrm{mg}$ catechin $/ 50 \mathrm{ml}$ and $2.66 \pm 0.000577 \mathrm{mg}_{\text {catechin }} / 50$ $\mathrm{ml}$ and vitamin $\mathrm{C}$ content were $0.41 \mathrm{mg} / 100 \mathrm{ml}, 0.63$ $\mathrm{mg} / 100 \mathrm{ml}$ and $0.7 \mathrm{mg} / 100 \mathrm{ml}$ for Mustard, Litchi and Nigella honey respectively.
\end{abstract}

Keywords Honey, Physico-chemical, Antioxidant, Polyphenol, Flavonoid

\section{Introduction}

Honey is a remarkable complex natural liquid reported to contain at least 181 substances. The composition of honey is rather variable and primarily depends on the floral sources; however, certain external factors also play the important role, such as seasonal and environmental factors and processing [1, 2]. Honey is the bees' produced royal nutritious sugary jelly, the world's healthiest food, available in all flavors and colors, processed applying natural regurgitation and evaporation techniques, processing the picked up nectar from the pollen of various flowers on nature [3]. It's is in use since long time both in medical and domestic needs, but recently its antioxidant property has come to limelight. It is rich in phenolic acids, flavonoids, ascorbic acid, carotenoid derivatives, organic acids, amino acids and proteins [4]. The dietary habit is changing day by day and the advice to take honey a day is a great saying to aid the nutritional well-being along with other food items with meal distribution patterns a day wisely [5]. Honey is the bees made sweet, thick, golden liquid food applying natural regurgitation and evaporation process within bees Gastrointestinal Tract (GIT) and stomach treating their consumed nectar collected from different types of flower available on the God gifted nature. Mustard honey is the bees made sweet, thick, yellowish liquid monofloral honey applying natural regurgitation and evaporation process within bees GIT and stomach treating their consumed nectar collected from the pollen of respective flower on the nature having a distinctive color, flavor and taste because of the principal nectar sources. Litchi honey is the widely used honey originated from natural nectar collected from Litchi flower at the orchards. It's variable use due to its distinctive aroma, texture and flavor. Nigella honey is the bees made sweet, thick, black-diamond semiliquid monofloral honey applying natural regurgitation and evaporation process within bees GIT and stomach treating their consumed nectar collected from the pollen of nigella flower on the nature having a distinctive color, flavor, taste because of the principal nectar sources [6]. Honey contains a number of compounds and the antioxidant properties of honey are well known [7-9]. The amount and type of these antioxidants are largely dependent on the floral source or honey variety, and a correlation between antioxidant activity with total phenolic content has been established [7,9]. Honey represents a natural product devoid of harmful side effects. Among the compounds found in honey; vitamin C, phenolic substances showed antioxidant properties. High 
levels of these indicators make sure a high level of antioxidants in honey. In Islam, there is an entire Surah in the Qur'an called al-Nahl (the Bee). According to hadith, Prophet Muhammad (Sm.) strongly recommended honey for healing purposes [10]. The Qur'an promotes honey as a nutritious and healthy food. Below is the English translation of those specific verses. "And thy Lord taught the Bee to build its cells in hills, on trees, and in (men's) habitations; Then to eat of all the produce (of the earth), and find with skill the spacious paths of its Lord: there issues from within their bodies a drink of varying colors, wherein is healing for men: verily in this is a Sign for those who give thought" [11]. The objectives of the study are to comparative evaluation of the physical, chemical and antioxidant properties of Mustard, Litchi and Nigella honey.

\section{Methodology}

\subsection{Place of Experiment and Sample Collection}

The study was carried out at Food Technology and Nutritional Science (FTNS) laboratory of Mawlana Bhashani Science and Technology University (MBSTU), Santosh, Tangail, Biochemistry and Molecular Biology laboratory of Jahangirnagar University (JU) and Bangladesh Council of Scientific and Industrial Research (BCSIR), Dhanmondi, Dhaka. The topic sample, Mustard (Brassica alba), Litchi (Nephelium litchi Cambess) and Nigella (Nigella sativa) honey (number of samples analyzed $=10$ for each) by name was collected from different honey producing farm in Tangail, Bangladesh. The study was continued from the $2^{\text {nd }}$ week of July 2013 to the $1^{\text {st }}$ week of February 2014 based on the selected honey sample.

\subsection{Physicochemical Quality Analysis}

Estimation of moisture, protein, ash content, Carbohydrate, Energy, TEF and vitamin $\mathrm{C}$ were determined by AOAC method-2005 [12], The TSS of the samples was determined by a hand refractometer, Minerals and heavy metal content of sample were determined by Atomic Absorption Spectrophotometer (AAS) and Flame Emission Spectrophotometer, $\mathrm{Na}$ and $\mathrm{K}$ were determined by Flame Emission Spectrophotometer, The total polyphenol was determined applying the Folin-Ciocalteu's method, The total flavonoid was determined applying Aluminum chloride colorimetric assay method and Absorption Spectrophotometer was used to measure Calcium (Ca), Magnesium (Mg), Iron (Fe) and Lead (Pb) [12].

\subsection{Data Analysis}

Statistical mean, median, mode, standard deviation (SD) and range were determined using SPSS 16 programme. For linear, tabular, chart and graphical representation, Microsoft Word and Microsoft Excel were used in the respective arena.

\section{Results and Discussion}

\subsection{Nutrient Contents of Mustard, Litchi and Nigella Honeys}

Table 1 shows the nutrient contents of Mustard, Litchi and Nigella honeys. The mean moisture content in the investigated Mustard, Litchi and Nigella honey sample was $14.32 \%, 15.27 \%$ and $14.12 \%$ respectively contributing within the limit $\leq 20 \%$ recommended by the international regulations [13]. The protein content of the Mustard honey was highest among the three samples. The ash content of the Mustard, Litchi and Nigella honey sample was almost same. Therefore, Nigella honey was in the best quality due to its low moisture, highest total carbohydrate, the Mustard honey was better and Litchi honey was in good quality.

Table 1. Nutrient contents of Mustard, Litchi and Nigella honeys

\begin{tabular}{|c|c|c|c|}
\hline Nutrient contents & $\begin{array}{c}\text { Mustard honey } \\
(\%)\end{array}$ & $\begin{array}{c}\text { Litchi } \\
\text { honey (\%) }\end{array}$ & $\begin{array}{c}\text { Nigella } \\
\text { honey (\%) }\end{array}$ \\
\hline Moisture & 14.32 & 15.27 & 14.12 \\
\hline Protein & 1.103 & 0.57 & 0.985 \\
\hline Ash & 0.2 & 0.19 & 0.188 \\
\hline TSS & 71 & 70 & 73 \\
\hline Total carbohydrate & 84.377 & 83.97 & 84.496 \\
\hline
\end{tabular}

\subsection{Antioxidant Contents of Mustard, Litchi and Nigella Honeys}

Table 2 shows the Antioxidant contents of Mustard, Litchi and Nigella honeys. Among three samples Nigella honey contained highest amount of polyphenol and Litchi honey contained the lowest amount of polyphenol. Result showed that Nigella honey also contained highest amount of flavonoid among three samples. The result was similar to a previous study in which honey samples also contained high polyphenol and flavonoid content [14]. The vitamin C content were $0.41 \mathrm{mg} / 100 \mathrm{ml}, 0.63 \mathrm{mg} / 100 \mathrm{ml}$ and 0.7 $\mathrm{mg} / 100 \mathrm{ml}$ for Mustard, Litchi and nigella honey respectively were detected, indicating that the observed honeys contribute a high antioxidant potential. Thus, the study revealed that Mustard, Litchi and Nigella honey were good sources of antioxidants and other nutrients. Therefore, Nigella honey was in the best quality due to its high polyphenol, flavonoid and vitamin $\mathrm{C}$ content.

Table 2. Antioxidant contents of Mustard, Litchi and Nigella honeys

\begin{tabular}{|c|c|c|c|}
\hline $\begin{array}{c}\text { Types of } \\
\text { honey }\end{array}$ & $\begin{array}{c}\text { Polyphenol } \\
\left(\mathrm{mg}_{\text {gallic acid }} / 50 \mathrm{ml}\right)\end{array}$ & $\begin{array}{c}\text { Flavonoid } \\
\left(\mathrm{mg}_{\text {catechin acid }} / 50 \mathrm{ml}\right)\end{array}$ & $\begin{array}{c}\text { Vitamin C } \\
(\mathrm{mg} / 100 \\
\mathrm{ml})\end{array}$ \\
\hline Mustard & $42.572 \pm 0.00529$ & $1.052 \pm 0.000577$ & 0.41 \\
\hline Litchi & $30.625 \pm 0.00529$ & $0.6 \pm 0.000577$ & 0.63 \\
\hline Nigella & $95.5 \pm 0.00529$ & $2.66 \pm 0.000577$ & 0.7 \\
\hline
\end{tabular}

Table 3. Biochemical analysis of Mustard, Litchi and Nigella honeys

\begin{tabular}{|c|c|}
\hline Types of honey & $\mathrm{P}^{\mathrm{H}}$ value \\
\hline Mustard & 6.97 \\
\hline Litchi & 5.8 \\
\hline Nigella & 4.78 \\
\hline
\end{tabular}


Table 4. Minerals and heavy metal analysis of Mustard, Litchi and Nigella honeys

\begin{tabular}{|c|c|c|c|c|c|c|}
\hline Types of honey & \multicolumn{4}{|c|}{ Major minerals (ppm) } & \multicolumn{1}{c|}{$\begin{array}{c}\text { Essential } \\
\text { minerals (ppm) }\end{array}$} & $\begin{array}{c}\text { Others } \\
(\mathrm{ppm})\end{array}$ \\
\hline & $\mathrm{Na}$ & $\mathrm{K}$ & $\mathrm{Ca}$ & $\mathrm{Mg}$ & $\mathrm{Fe}$ & $\mathrm{Pb}$ \\
\hline Mustard & 539.238 & 239.216 & 1710.499 & 267.799 & 63.70 & 0.1 \\
\hline Litchi & 424.3565 & 219.017 & 611.4852 & 143.066 & 251.1102 & 1.8 \\
\hline Nigella & 588 & 1063.774 & 75.4 & 58.8471 & 344.2112 & 5.6 \\
\hline
\end{tabular}

\subsection{Biochemical Analysis}

Table 3 represents the biochemical analysis of Mustard, Litchi and Nigella honeys. The mean $\mathrm{P}^{\mathrm{H}}$ content was 6.97, 5.8 and 4.78 for the Mustard, Litchi and Nigella honey respectively. The average $\mathrm{pH}$ of honey is 3.9 , but can range from 3.4 to 6.1. Honey contains many kinds of acids, both organic and amino. However, the different types and their amounts vary considerably, depending on the type of honey $[15,16]$. Among the three specimens Nigella and Litchi honey was expected $\mathrm{pH}$. Mustard honey was contained slightly high $\mathrm{P}^{\mathrm{H}}$ value. The $\mathrm{P}^{\mathrm{H}}$ value was similar to those previously reported for other honey samples from India, Spain, Brazil, Malaysia and Turkey [17, 18].

\subsection{Minerals and Heavy Metal Analysis}

Table 4 shows the Minerals and heavy metal analysis of Mustard, Litchi and Nigella honeys. The Na and K content of investigated Mustard honey were measured $539.238 \mathrm{ppm}$ and $239.216 \mathrm{ppm}$ respectively as well as the $\mathrm{Ca}, \mathrm{Mg}, \mathrm{Fe}$ and $\mathrm{Pb}$ content were measured.1710.499 ppm, 267.799 ppm, $63.70 \mathrm{ppm}$ and BDL (Bellow Detection Limit) respectively. The $\mathrm{Na}$ and $\mathrm{K}$ content of investigated Litchi honey were measured $424.3565 \mathrm{ppm}$ and $219.017 \mathrm{ppm}$ respectively. The $\mathrm{Na}$ and $\mathrm{K}$ content of investigated Nigella honey were measured $558 \mathrm{ppm}$ and $1063.774 \mathrm{ppm}$ respectively. Among three honey samples Nigella honey contained highest amount of lead $(\mathrm{Pb})$ and Mustard honey contained lowest amount of lead $(\mathrm{Pb})$ and the acceptable blood $\mathrm{Pb}$ level for adults is $10 \mu \mathrm{g} / \mathrm{dl}[19]$.

\section{Conclusions}

The present study concluded that three honey sample showed the good physicochemical potentials, pointing the low moisture content, $\mathrm{pH}$, high TSS, the lowest protein, ash, mineral contents as well as the outstanding antioxidant potentials, pointing the high polyphenols, flavonoids and vitamin $\mathrm{C}$ contents. On the basis of employed analytical methods, among three specimens of honey samples Nigella honey contains lowest moisture, $\mathrm{p}^{\mathrm{H}}$ content than that of Mustard and Litchi honey. Investigated honey samples rich in antioxidant compounds promising pharmacological agent for preventing cancer. The antioxidant potential, such as polyphenol, flavonoid and vitamin $\mathrm{C}$ were highest in Nigella honey than the others two specimens. The ash and mineral were highest in Mustard honey than the others two specimens. Under the circumstances stated above, there was no confusion of Nigella honey being the best, Mustard the better as well as Litchi honey the good according to CAC given honey quality parameters.

\section{REFERENCES}

[1] Bryant, Vaughn M., Jr. (2001). Pollen Contents of Honey, CAP Newsletter 24 (1): 10-24.

[2] Whitmyre, Val. The Plight of the Honeybees. University of California. April 14, 2007.

[3] National Honey Board. Carbohydrates and the Sweetness of Honey, June 01, 2012

[4] Waikato Honey Research Unit. June 02, 2007.

[5] Sharma, Rajeev (2005). Improve your Health! With Honey. Diamond Pocket Books. pp. 33-ISBN 978-81-288-0920-0.

[6] The Colours of Honey. National Honey Broad, February 06, 2011.

[7] Al, M.L.; Daniel, D.; Moise, A.; Bobis, O.; Laslo, L.; Bogdanov, S. Physico-chemical and bioactive properties of different floral origin honeys from Romania. Food Chem. 2009, 112, 863-867. 6.

[8] Ferreira, I.C.F.R.; Aires, E.; Barreira, J.C.M.; Estevinho, L.M. Antioxidant activity of portuguese honey samples: Different contributions of the entire honey and phenolic extract. Food Chem. 2009, 114, 1438-1443. 7.

[9] Gheldof, N.; Engeseth, N.J. Antioxidant capacity of honeys from various floral sources based on the determination of oxygen radical absorbance capacity and inhibition of in vitro lipoprotein oxidation in human serum samples. J. Agric. Food Chem. 2002, 50, 3050-3055.

[10] Al-Bukhari M: Sahih Bukhari Nazi Publications. 3 Rev Edition edition. 740A.D, Chicago LISA; 1976.

[11] Yusuf 'Ali, 'Abdullah. An Nahl, Al-Quran Chapter 16 (The Bee) quoted from "The Holy Qur'an: Original Arabic Text with English Translation \& Selected Commentaries". Saba Islamic Media. May 20, 2013.

[12] AOAC (2005) Official methods of Analysis of AOAC, International, Washington, DC: Association of Official Analytical Chemist (1990). 16:1546.

[13] Codex Alimentarius Commission. Revise codex standard for honey. Codex standard 12-1982, Rev.1 (1987), Rev.2 (2001)1, COMESA/FDHS002:2004.

[14] Khalil, M; Alam, N; Moniruzzaman, M; Sulaiman, S; Gan, S. 
Phenolic acid composition and antioxidant properties of Malaysian honeys. J. Food Sci, 2011, 76, C 921-C928.

[15] Nutrient data for honey (1996). USDA nutrient data laboratory. $\mathrm{P}^{\mathrm{H}}$ and Acids in Honey. National Honey Board Food Technology/Product Research Program.

[16] Wilkins, Alistair L. and Lu, Yinrong (1995). "Extractives from New Zealand Honeys. 5. Aliphatic Dicarboxylic Acids in New Zealand Rewarewa (Knightea excelsa) Honey". J. Agric. Food Chem. 43 (12): 3021-3025.
[17] Azeredo, L.C; Azeredo, M.A.A; Souza, S.R;Dutra, V.M>L. Protein contents and physicochemical properties in honey samples of Apis mellifera of different floral origins. Food chem. 2003, 80, 249-254.

[18] Sexena, S; Gautam,S;Sharma, A. Physical, biochemical and antioxidant properties of some Indian honeys. Food chem. 2010, 118. 391-397.

[19] The National Institute for Occupational Safety and Health (NIOSH); 2013. 